\title{
Rевевсн Автісів: Radio listening behaviour and preferences of rural farmers in Raichur district of NE Karnataka
}

\author{
SYED RIYAJ KHADRI, S.B. GOUDAPPA AND SIDRAMAYYA
}

Article Chronicle: Received : 19.07.2017; Accepted : 03.08.2017

KEY Words:

Radio, Respondents, Listening behaviour, Farmers, Preference
SUMMARY : The study was conducted in Raichur district of North Karnataka, during the year 2013-14 by following purposive sampling 120 respondents were selected from the district. The data was elicited through personnel interview method and analyzed using mean, standard deviation, frequency, percentage and correlation. The major findings of the study indicate completely radio listening behaviour of the respondents to different farm and home radio programmes and reveals that respondents listening behaviour of the farm programmes regularity of listening priority of live phone in programmes $(45.83 \%)$ and progressive farmer interviews $(41.67 \%)$, discussing on burning topics $(37.50 \%)$, experts interviews $(40.00 \%)$ and special talks $(35.00 \%)$. Among home programme gelayara balaga $(46.67 \%)$, radio doctor $(45.00 \%)$ and health programme $(44.17 \%)$ and mahila ranga $(14.17 \%)$ were in order of regularity in listening. It is also reveling to note that, 40 per cent of the respondents spent 'full time' in listening the farm programmes such as progressive farmer interviews, experts interviews, live phone in programmes, discussing on burning topic and special talk in order. On the contrary, the respondents were also spent their time on listening home programmes such as gelayara balaga (40.83\%), radio doctor (40.00\%) and health programme $(38.33 \%)$ as full time in order. With regards to attention of the respondents to farm and home programmes, nearly (80.00\%) of the listener paid 'full attention' and 'attention' to the enlisted farm and home radio programmes. It is also evident that the variables viz., education, farming experience and family size were significantly related with listening behaviour. There was no significant relationship between method of listening and age, extension orientation, mass media participation, scientific orientation, management orientation and innovativeness. It is clear that, nearly one third of the radio listener preferred the live phone in agricultural and allied sector programmes as a most preferred method of presentation.

How to cite this article : Khadri, Syed Riyaj, Goudappa, S.B. and Sidramayya (2017). Radio listening behaviour and preferences of rural farmers in Raichur district of NE Karnataka. Agric. Update, 12(TECHSEAR-7) : 19901994; DOI: 10.15740/HAS/AU/12.TECHSEAR(7)2017/1990-1994.
Author for correspondence :

\section{SYED RIYAJ KHADRI}

Department of

Agricultural Extension

Education, University of Agricultual Sciences, RAICHUR (KARNATAKA) INDIA

See end of the article for authors' affiliations 